\title{
Mudar atitudes, mudar valores
}

O sorriso expressa, numa primeira acepção, alegria, amabilidade, contentamento e aprovação. Proporcionar liberdade e segurança para a manifestação desses sentimentos é um dos objetivos da Odontologia. Essa meta se confronta hoje com um novo desafio, que é o de contribuir para a manutenção dessas experiências ao longo de uma existência longeva.

O processo de seleção natural forjou as estruturas dentárias humanas para que cumprissem seus deveres ao longo das poucas décadas de vida que tínhamos. Os avanços médicos alongaram a expectativa de vida e, atualmente, a Odontologia precisa planejar e executar tratamentos para pessoas que possuem grande probabilidade de ultrapassar os 80 anos.

Entretanto, os dentes naturais não são preparados para esse emprego, tampouco os artificiais. A dentição precisa ter sua estrutura preservada e restaurações precisam ser esteticamente agradáveis e durar muitos anos, a despeito da principal função do dente envolver atrito constante.

O problema a ser gerenciado se torna ainda maior quando se adiciona a essa equação o fato de não apenas as pessoas desejarem viver mais: elas querem viver melhor. Como oferecer o mais e o melhor e harmonizar a oferta com os limites biológicos? A resposta é ... mudar.

Mudar atitudes e mudar valores. Aprender a adquirir conhecimento e, acima disso, incorporar as novas informações à rotina clínica. Entender as novas necessidades de nossos pacientes e se apurar para ajudá-los melhor. Isso significa considerar, sempre, o tempo, o envelhecimento e os possíveis fatores deletérios à dentição. Também representa aprimorar o senso crítico para tratamentos que, muitas vezes, são lindos quando apresentados sem um acompanhamento de anos, mas que têm pouca chance de reter seus resultados de forma duradoura.

Uma importante leitura com esse escopo é o artigo intitulado "Bruxismo do sono", da Dra. Cristiane R. de Macedo. Ela, que tem uma revisão sistemática Cochrane sobre a efetividade das placas oclusais, publica nesse número uma excelente revisão sobre o bruxismo ${ }^{1}$. A leitura, na íntegra, de seu trabalho é fortemente recomendável.

Outro artigo em sintonia direta com os novos tempos é o de Valle-Corotti et al. sobre a Ortodontia na atuação odontogeriátrica ${ }^{2}$. Os autores salientam a necessidade de se incorporar um olhar levemente diferente do convencional ao tratar pacientes idosos e mostram a aplicação desses fundamentos, por meio de casos clínicos.

Estar alinhado com os anseios de nossos pacientes é estar na direção correta. A compreensão desse passo é determinante para contribuir com um futuro melhor.

Boas mudanças.

Jorge Faber

Editor

\section{REFERÊNCIAS}

1. MACEDO, C. R. Bruxismo do sono. R. Dental Press Ortodon. Ortop. Facial, Maringá, v. 13, n. 2, p. 18-22, mar./abr. 2008.

2. VALLE-COROTTI, K. M.; VALLE, C. V. M.; NEVES, L. S.

HENRIQUES, J. F. C.; PINZAN, A. A Ortodontia na atuação odontogeriátrica. R. Dental Press Ortodon. Ortop. Facial, Maringá, v. 13, n. 2, p. 84-93, mar./abr. 2008. 